\title{
Косякова Л.Н., Попова А.Л. Влияние ограничения импорта сельскохозяйственной продукции на процессы освоения инноваций в АПК РФ
}

\author{
Kosyakova L.N., Popova L.A. \\ The impact of import restrictions for agricultural products on the \\ processes of development of innovations in agrarian and \\ industrial complex of the Russian Federation
}

В статье рассматриваются вопросы о влияние ограничения импорта сельскохозяйственной продукции на процессы освоения инноваций в агропромышленном комплексе России

Ключевые слова: санкции, сельскохозяйственная продукция, сокращение объема импорта, эмбарго, процессы освоения инноваций

\section{Косякова Людмила Николаевна}

Кандидат экономических наук, доцент

Санкт-Петербургский государственный аграрный университет

Санкт-Петербург, г. Пушкин, Петербургское ш., 2

\section{Попова Алла Леонидовна}

Санкт-Петербургский государственный аграрный университет

Санкт-Петербург, г. Пушкин, Петербургское ш., 2

\begin{abstract}
The article discusses the impact of the restrictions on imports of agricultural products on the processes of development of innovations in the agro-industrial complex of Russia

Key words: sanctions, agricultural products, imports, embargo, development innovation
\end{abstract}

\author{
Kosyakova Lyudmila Nikolaevna \\ Candidate of Economic Sciences, Associate Professor \\ St. Petersburg state agrarian university \\ St. Petersburg, Pushkin, Petersburg highway st., 2
}

\section{Popova Alla Leonidovna}

Candidate of Economic Sciences, Associate Professor St. Petersburg state agrarian university

St. Petersburg, Pushkin, Petersburg highway st., 2

На протяжении уже нескольких десятилетий человечество переживает переход к экономическим отношениям нового типа: повсеместно речь идет о формировании и развитии информационной экономики, экономики знаний и т.п. [1]. Вместе с тем, нельзя забывать о необходимости существования традиционных отраслей материального производства, обеспечивающих неуклонно численно увеличивающееся население Земли продуктами питания, предметами обихода, а новые сферы экономики - необходимыми материальными ресурсами. Условия существования традиционных производств, в том числе сельского хозяйства, изменились и продолжат изменяться в дальнейшем. Они будут всё больше уходить «в тень» стремительно развивающихся отраслей новой экономики, соответственно, всё меньше ресурсов будет в них задействовано. 
Первый заметный отток ресурсов из сельского хозяйства произошёл в период индустриализации, сейчас происходит второй. Бороться с этим процессом сейчас бессмысленно, так как это противоречило бы общим тенденциям развития нашей цивилизации. Следует приспособить отечественное сельскохозяйственное производства к новым условиям функционирования, а именно к необходимости производить большие объёмы продукции, используя минимальное количество ресурсов.

Решить указанную проблему возможно, проводя постоянную технологическую интенсификацию производства, но тут возникает другая проблема: для разработки, апробации и внедрения новых технологий необходимы значительные долгосрочные инвестиции, а сельское хозяйство в нашей стране является традиционно малорентабельной сферой экономической деятельности, мало привлекательной для инвесторов [2]. Кроме того, макроэкономический процесс оттока ресурсов, прежде всего, трудовых и финансовых, из сельского хозяйства в нашей стране совпал с кризисом отрасли, вызванным резкими изменениями принципов управления экономикой, формы собственности, системы социально-экономических взаимодействий. В результате качественные и даже количественные показатели функционирования российского АПК заметно уступают показателям большинства стран.

Одной из основных проблем развития отечественного АПК на протяжении последних 25 лет считается излишний импорт сельскохозяйственной продукции. Действительно, наряду с традиционно импортируемыми (чай, кофе, какао-бобы, цитрусовые и т.п.) продуктами в нашу страну в больших объёмах ввозятся молоко и молочные продукты, мясо, рыба (таблица 1).

Таблица 1. Среднегодовые объёмы импорта в РФ отдельных видов сельскохозяйственной продукции в 2008-2014 годах

\begin{tabular}{|l|c|c|c|}
\hline \multicolumn{1}{|c|}{ Вид продукции } & тонн & $\begin{array}{c}\text { тыс. долл. } \\
\text { США }\end{array}$ & доля, \% \\
\hline Мясо свежее и мороженое, т & 1450575 & 5071449 & 47,19 \\
\hline Мясо птицы свежее и мороженое, т & 740214 & 974883 & 9,07 \\
\hline Рыба свежая и мороженая, т & 780656 & 1826937 & 17,00 \\
\hline Молоко и сливки сгущенные, т & 177608 & 486970 & 4,53 \\
\hline $\begin{array}{l}\text { Масло сливочное и прочие молочные жи- } \\
\text { ры, т }\end{array}$ & 132022 & 502007 & 4,67 \\
\hline Злаки, т & & & \\
\hline Пшеница, т & 858561 & 404630 & 3,76 \\
\hline Ячмень, т & 241187 & 62865 & 0,58 \\
\hline Кукуруза, т & 243119 & 85356 & 0,79 \\
\hline Масло подсолнечное, т & 107895 & 112393 & 1,05 \\
\hline Изделия и консервы из мяса, т & 66500 & 84099 & 0,78 \\
\hline Сахар сырец, т & 45212 & 200519 & 1,87 \\
\hline Сахар белый, т & 1522979 & 811816 & 7,55 \\
\hline Итого & 183020 & 123916 & 1,15 \\
\hline
\end{tabular}

* по данным Федеральной службы государственной статистики РФ [3] 
Основу импорта продовольствия в РФ составляет мясо свежее и мороженное, отечественная мясоперерабатывающая промышленность работает преимущественно на зарубежном сырье. В 2008-2014 годах основными импортерами продовольствия в РФ были страны дальнего зарубежья.

Согласно распространенному среди специалистов, и не только, мнению, ограничения импорта продовольствия в РФ на государственном уровне - обязательное условие вывода отечественного АПК из состояния системного кризиса [1]. В этом контексте события августа 2014 года могут рассматриваться как благоприятные для сельского хозяйства РФ. 6 августа Указом Президента России «О применении отдельных специальных экономических мер в целях обеспечения безопасности Российской Федерации» был запрещён ввоз на территорию РФ отдельных видов сельскохозяйственной продукции, сырья и продовольствия, страной происхождения которых является государство, принявшее решение о введении экономических санкций в отношении российских юридических и (или) физических лиц или присоединившееся к такому решению. Под действие эмбарго попали страны ЕС, США, Австралия, Канада, Норвегия. Конкретный перечень товаров, в отношении которых вводятся ограничения, определило правительство РФ. В список входят мясные и молочные продукты, рыба, овощи, фрукты и орехи. Суммарный годовой объём импорта, подпавшего под санкции, оценивается в 9 миллиардов долларов США.

20 августа правительство Российской Федерации исключило из санкционного списка безлактозное молоко, мальков лосося и форели, семенной картофель, лук, гибридную сахарную кукурузу и лук, биологически активные добавки.

Последствия введённых санкций для экономики РФ начали проявляться в сентябре-октябре 2014 года, до тех пор использовались запасы ранее ввезенной продукции. «Работать» санкции будут по цепочке «производствопереработка-продажа» начиная с последнего звена, т.е. сначала изменения коснутся торговых организаций, затем - перерабатывающих, и лишь потом сельскохозяйственных.

В сфере торговли санкции привели к сокращению потребления основных видов продовольствия, а так же повышению розничных цен на сельскохозяйственную продукцию. При этом уровень рентабельности торговых организаций снизился.

Учитывая, что эмбарго введено сроком на 1 год с возможностью продления, под его воздействие попадают фьючерсные продажи урожая следующего года. Вероятность скорого инвестирования значительных ресурсов в долгосрочные производственные проекты мала, но возможно увеличение объёмов финансирования в «скороспелых» отраслях животноводства (птицеводство, свиноводство) и овощеводстве [4].

Возможные последствия эмбарго для АПК РФ можно оценить, сопоставляя динамику объёмов импорта отдельных групп продовольственных товаров (рис.1) и показатели уровня развития отечественного сельского хозяйства. 


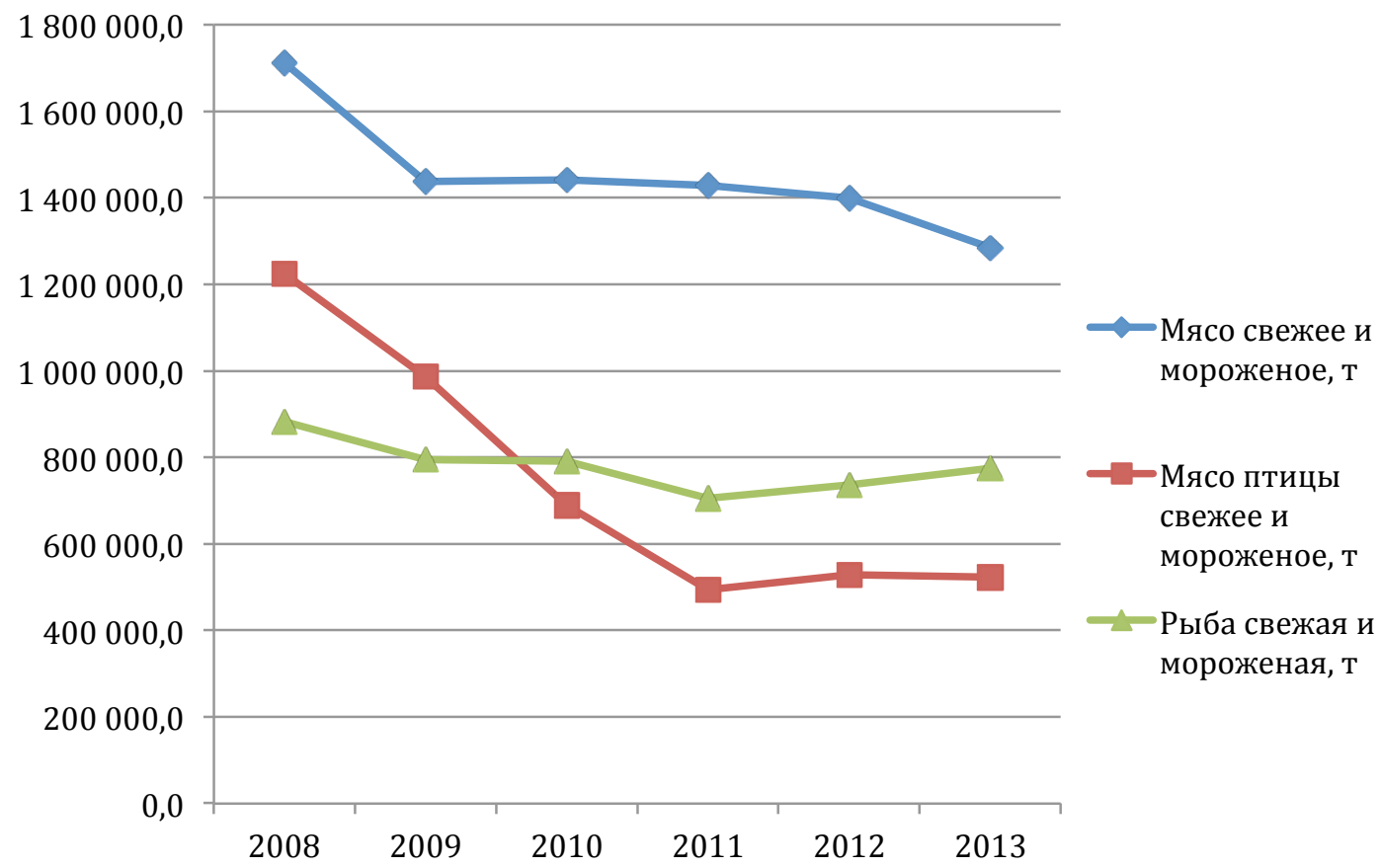

Рис. 1. Импорт в РФ отдельных видов продовольствия, тонн

* по данным Федеральной службы государственной статистики РФ [3]

На рисунке 1 представлена динамика объёмов импорта трёх основных групп продовольственных товаров. По всем группам в период 2008-2013 годов наблюдается сокращение импорта, в наибольшей степени сокращался ввоз мяса и мяса птицы, ввоз рыбы сократился в 2008-2011 годах, затем начал незначительно увеличиваться.

Резкое уменьшение импорта мяса в 2008-2010 годах объясняется финансовым кризисом и последовавшим увеличением цен на продовольствие на мировом рынке. Одновременно наблюдалось сокращение платёжеспособного спроса на мясо, мясопродукты и рыбу на российском потребительском рынке. После выравнивания ситуации на потребительском рынке объёмы импорта не вернулись на докризисный уровень.

В том же периоде (2008-2013 годы) отечественное животноводство характеризовалось следующими показателями (таб.2).

Таблица 2. Производство продуктов животноводства в расчете на 100 га сельскохозяйственных угодий, тонн

\begin{tabular}{|l|c|c|c|c|c|c|}
\hline Вид продукции & 2008 & 2009 & 2010 & 2011 & 2012 & 2013 \\
\hline Скот и птица на убой (в живом весе) & 3,8 & 4,4 & 5,0 & 5,4 & 6,1 & 6,8 \\
\hline Молоко & 11,1 & 11,6 & 11,7 & 11,8 & 12,2 & 11,7 \\
\hline
\end{tabular}

* по данным Федеральной службы государственной статистики РФ[3]

Сокращение импорта мяса в РФ в 2008-2013 годах сопровождалось развитием отечественного мясного животноводства, что выразилось в увеличении производства продукции в расчёте на 100 га сельскохозяйственных угодий. 
Кроме сокращения импорта, на развитие животноводства положительно влияли мероприятия, проводимые в рамках национального проекта развития АПК.

Таким образом, статистические данные 2008-2013 годов свидетельствуют о том, что сокращение объема импорта продовольственных товаров в сочетании с комплексом мер по государственной поддержке товаропроизводителей может привести к заметному улучшению ситуации в отечественном сельском хозяйстве в течение 3-5 лет, в зависимости от отрасли.

\section{Список литературы:}

1. Косякова Л.Н. Организационно-экономический механизм освоения инноваций - основа продовольственной безопасности страны // Известия международной академии аграрного образования. 2014. №20. С. 81-83.

2. Смекалов П.В., Берсенева Н.С., Кузьмина О.В. Анализ и оценка инвестиционной привлекательности предприятий АПК // Научное обеспечение развития АПК в условиях ребормирования. СПбГАУ. 2013. 3. Федеральная служба государственной статистики. URL: http://www.gks.ru 4. Еникеев В.Г., Попова А.Л., Нуттунен П.А. Процедуры многоуровневого индикативного планирования АПК // Известия Международной академии аграрного образования. 2012. T. 2. № 15. C. 38-47.

(C) 2015, Косякова Л.Н., Попова А.Л. Влияние ограничения импорта сельскохозяйственной продукции на процессы освоения инноваций в АПК РФ
(C) 2015, Kosyakova L.N., Popova L.A.

The impact of import restrictions for agricultural products on the processes of development of innovations in agrarian and industrial complex of the Russian Federation 